\title{
Trace element uptake dynamics for maize (Zea mays L.) grown under field conditions
}

\author{
Mauricio Molina • Mauricio Escudey • \\ Andrew C. Chang • Weiping Chen • \\ Nicolás Arancibia-Miranda
}

Received: 13 August 2012 / Accepted: 31 January 2013 /Published online: 23 February 2013

(C) Springer Science+Business Media Dordrecht 2013

\begin{abstract}
Background and aims The trace element uptake process of plants is a key factor in assessing the risks of trace element build-up in agricultural soils. Scarce information exists on the trace element dynamic uptake of plants grown in the field, especially on those potentially hazardous. In this study, the uptake process of $\mathrm{As}, \mathrm{Cd}, \mathrm{Cu}$, and $\mathrm{Zn}$ in maize plants was quantified and characterized throughout the entire season.

Methods Along two seasons, the uptake dynamics of field-grown maize plants in absorbing the soil borne trace elements was examined. Biomass production and the concentration of the elements in plant and soil solution samples were determined. A kinetic model was employed to characterize the uptake by plants.
\end{abstract}

Responsible Editor: Fangjie Zhao.

M. Molina $(\triangle)$

Departamento de Industrias, Universidad Técnica Federico

Santa María, Av. Santa María \#6400, Vitacura, Santiago

7660251, Chile

e-mail: mauricio.molina@usm.cl

M. Escudey $\cdot$ N. Arancibia-Miranda

Facultad de Química y Biología, Universidad de Santiago

de Chile, Casilla 40 Correo 33, Santiago, Chile

\section{A. C. Chang}

Department of Environmental Sciences, University

of California, Beijing 100085, China
Results The kinetic parameters of the uptake process, maximum cumulative uptake rate, $U_{\max }$, time to reach $50 \%$ of $U_{\max }, t_{U 50}$, and reciprocal of the uptake rate, $b_{U}$ when followed throughout the season in terms of the plant's growing degree days remained constant between seasons and were element specific. In spite of the large amount biomass produced, maize plants extracted minute quantities of $\mathrm{Cd}$ and As. Increasing cumulative uptake rates of $\mathrm{As}, \mathrm{Cd}, \mathrm{Cu}$, and $\mathrm{Zn}$ from the soil took place primarily in the early half of the growing season when the biomass accumulation was still less than $50 \%$ of the maximum harvested biomass. The element-specific plant uptake factor (PUF), which denote the partition of trace elements between the soil solution and plant phases, decreased following

W. Chen

State Key Lab of Urban and Regional Ecology, Research Center for Eco-Environmental Sciences, Chinese Academy of Sciences, Riverside, CA 92521, USA

M. Escudey $\cdot$ N. Arancibia-Miranda Center for the Development of Nanoscience and Nanotechnology, CEDENNA, Santiago 9170124, Chile 
a first-order kinetics along the growing period, did not show any significant difference between seasons, and, at maturity stage, followed the sequence $\mathrm{Cd} \geq \mathrm{Zn}>\mathrm{Cu} \geq$ As.

Conclusions The uptake process of the elements was adequately described by the kinetic model, showing similar patterns but different magnitude and distribution in the plant. The extraction of Cd and As by plants is low in comparison to common inputs through fertilizer applications into maize production systems, indicating potential risk of trace element accumulation in soils. The PUF may be estimated according to the kinetics parameters of the uptake process. On a per-unit-soil solution element basis, $\mathrm{Cd}$ and $\mathrm{Zn}$ would be more susceptible to the soil-to-plant transfer than $\mathrm{As}$ and $\mathrm{Cu}$.

Keywords Arsenic $\cdot$ Cadmium $\cdot$ Copper $\cdot$ Zinc $\cdot$ Uptake kinetics $\cdot$ Bioaccumulation index

\section{Introduction}

Trace elements, in metallic and metalloid forms, are ubiquitous in the terrestrial environment. While many are essential for the livelihood of biota in minute quantities, practically all of them have adverse biochemical effects if thresholds are exceeded (Pierzynski et al. 2005). Through anthropogenic activities, trace elements accumulate and become enriched in terrestrial ecosystems, thus entering the soil-plant continuum and being inadvertently transferred along the food chain to harm humans and foraging animals. Global circulation and atmospheric fallouts, mineral extraction and smelting, industrial emission, fertilizer application, and waste disposal are common modes of their transmissions (Chang and Page 2000; Dach and Starmans 2005; Nicholson et al. 2003).

Plant uptake would be a key process to evaluate environmental risks of trace element accumulation in soils. However, there are comparatively few studies that monitored the trace elements uptake dynamics for field-grown plants, especially of potentially hazardous elements. The concentrations of trace elements in harvested plant tissues may be experimentally related to those of the corresponding soils on which the plants were grown (Guttormsen et al. 1995; Huang et al. 2006). In risk assessment, the plant uptake of trace element from soils is customarily characterized by a linear transfer coefficient namely the plant uptake factor, $P U F$ (L soil solution $\mathrm{kg}^{-1}$ biomass), based on experimental data that:

$P U F=C_{\text {plant }} / C_{S S}$

where $C_{\text {plant }}$ denotes the trace element concentration in plant tissues $\left(\mathrm{mgkg}^{-1}\right)$ and $C_{S S}$ denotes the trace element concentration of the soil solution in which the plants were grown $\left(\mathrm{mgL}^{-1}\right)$. Soil solution concentration is considered a good predictor of metal bioavailability (Gerritse et al. 1983; Kabata-Pendias and Pendias 2001). Free metal activity in the soil solution has been suggested to be the best indicator of metal bioavailability (Minnich et al. 1987; Parker et al. 1995), however, it is more difficult to determinate on a routine basis. In turn, $C_{s s}$ can be estimated through a linear trace element distribution coefficient, $K_{d}\left(\mathrm{~L} \mathrm{~kg}^{-1}\right)$ that:

$K_{d}=C_{\text {total }} / C_{s s}$

where $C_{\text {total }}$ denoted the total trace element concentration of soil $\left(\mathrm{mg} \mathrm{kg}^{-1}\right)$. The distribution coefficient strongly depend on soil properties like $\mathrm{pH}$, clay and organic matter content, involves the global trace element-soil interactions, and has been used to assess the fate of metals in soils (Sauvé et al. 2000).

The element-specific PUF of a plant species is considered to be constant at a given time (e.g., harvest) and soil conditions, and can be obtained from outcomes of cultivating plants under field conditions (Huang et al. 2006; Soriano and Fereres 2003) or short-term potting cultures (Lehoczky et al. 2006; Lorenz et al. 1997). Chen et al. (2009a) showed that $P U F$ of selected food crops grown in fields in California exhibited a normal distribution with rather narrow data dispersions.

The transfer factor described by Eq. 1, PUF, is empirical in nature. It indicates steady state conditions and a linear mass transfer of trace elements between those in the soil solution and those absorbed by plants, and it doesn't take into consideration the dynamic interactions between root and soil in the nutrient absorption process. Besides, the trace element uptake rates vary among elements (Mullins and Sommers 1986), chemical species of an element (Abedin et al. 2002; Habbas and Meharg 2008), and due to soil environment conditions (Perriguey et al. 2008). 
Conceptual considerations

Michaelis-Menten kinetic model has been used to characterize dynamics of elemental uptake by plants:

$J=\frac{J_{\max } \times C_{s s}}{K_{m}+C_{s s}}$

where $J\left(\mathrm{mg} \mathrm{cm}^{-1}\right.$ root day $\left.{ }^{-1}\right)$ is the trace element influx rate of plant root and is a function of trace element concentration in the solution phase, $C_{S S}$ (in this case $\left.\mu \mathrm{gL}^{-1}\right), J_{\max }\left(\mathrm{mg} \mathrm{cm}^{-1}\right.$ root day $\left.{ }^{-1}\right)$ is the maximum solute uptake influx, and $K_{m}\left(\mathrm{mgL}^{-1}\right)=C_{s s}$ when $J=0.5 \times J_{\max }$ is the root permeability coefficient. The $C_{S S}$ is an overall result of the processes governing the chemical reactions of trace element in soils. The parameters $J_{\max }$ and $K_{m}$ represented characteristics of the plants and are considered constant for a plant species. The cumulative plant uptake rate, $U(t)(\mu \mathrm{g}$ $\mathrm{cm}^{-3}$ soil day ${ }^{-1}$ ) of time $t$, is obtained when uptake influx, $J$, is multiplied by the root density, $R(t)(\mathrm{cm}$ root $\mathrm{cm}^{-3}$ soil), that is a function of time, $t$ :

$U(t)=R(t) \times J=R(t) \times \frac{J_{\max } \times C_{s s}}{K_{m}+C_{s s}}$

The total uptake is obtained by integrating Eq. 4 over the growing period as the root density is a function of time, $t$.

The Michaelis-Menten kinetic model empirically depicts the processes through which plants absorb nutrients and contaminants (Darrah and Staunton 2000; Silberbush et al. 2005). However, this approach is problematic for modeling the uptake process under realistic conditions. It was challenging to adopt this model for crops growing under the field conditions (BassiriRad et al. 1999). The $\mathrm{J}_{\max }$ and $\mathrm{K}_{\mathrm{m}}$ have been obtained customarily under a steady state condition over a short growth period in laboratory settings (e.g., Abedin et al. 2002; Mullins and Sommers 1986). However, the uptake in the field is a dynamic non-steady-state process that depends on the growing conditions, plant age, and nutrient status (Steingrobe and Schenk 1994, and references therein). During the growing season, the root density and thus the total element uptake rise in proportion with time. It is difficult to measure the root density, and there is not a simple and accurate field-based technique to assess the time dependent change in root density (Tudoreanu and Phillips 2004).
Typically, the plant growth can be divided into phases of early accelerating, exponential, and final saturation growth stages toward maturity. The plant biomass and root density grow accordingly. The increase in the above-ground biomass (BM) over time generally follows a sigmoidal trend so that:

$B M(t)=\frac{B M_{\max }}{1+\exp ^{\frac{-\left(t-t_{B M 50}\right)}{b_{B M}}}}$

where $B M(t)$ is the cumulative biomass at time $t$ of the growing season, $B M_{\max }$ is the maximum biomass $(\mathrm{kg}$ $\mathrm{ha}^{-1}$ ) at the time of harvest, $b_{B M}$ (time unit) is the reciprocal of the growth rate, and $t_{B M 50}$ is the time for plant to reach $50 \%$ of $B M_{\max }$. To minimize effects on plant growth due to fluctuations of ambient temperatures, the plant growing time can be expressed in terms of cumulative plant growing degree days $\left(G D D,{ }^{\circ} \mathrm{C}\right.$-day). By normalizing the time scale in terms of plant GDD, $t_{B M 50}$ (in ${ }^{\circ} \mathrm{C}$-day) can be considered as a constant for a given species. In this manner, the $B M_{\max }$ may be estimated by measuring the plant biomass, $B M(t)$, at any time $t$ (in ${ }^{\circ} \mathrm{C}$-day). Assuming that plant uptake is proportional to the biomass of growing plants, the trace element cumulative uptake rate could be determined as (Chen et al. 2009b):

$U(t)=\frac{U_{\max }}{1+\exp ^{\frac{-\left(t-t_{U 50}\right)}{b_{U}}}}$

where $U(t)$ and $U_{\max }\left(\mathrm{gha}^{-1}\right.$ day $\left.^{1}\right)$ denote the cumulative uptake rate of trace element at time $t$ and at time of harvest, respectively, $b_{U}$ (time unit) was the reciprocal of the uptake rate, and $t_{U 50}$ is the time for plant to reach $50 \%$ of $U_{\max }$. Again, $\mathrm{t}_{U 50}$ can be expressed in terms of GDD.

By integrating the Michaelis-Menten and the uptake kinetics models, Chen et al. (2008, 2009b) characterized the Cd uptake by lettuce (Lactuca sativa L.) plants grown on an Entisol. The root density of growing plant is a function of its above ground biomass. With this assumption, the Eq. 4 can be written in terms of time-dependent changes in biomass, $B M(t)$, as follows:

$U(t)=B M(t) \times R_{\text {root-shoot }} \times \frac{J_{\max } \times C_{s s}}{K_{m}+C_{s s}}$ 
where $U(t)$ represents the cumulative plant uptake rate at time $t$ after seeding and $R_{\text {root-shoot }}$, the root-to-shoot ratio ( $\mathrm{cm}$ root $\mathrm{kg}^{-1}$ biomass), is a constant. This way it was possible to relate the actual uptake rates to the Michaelis-Menten parameters.

The total uptake (U) at time $t$ can be obtained from the element content in the plant tissue $\left(\mathrm{mgkg}^{-1}\right)$ and the corresponding biomass, $B M(t)$. By integrating Eq. 7 , the change of the element content in the plant tissue with time can be obtained:

$C_{\text {plant }}(t)=C_{s s} \times P U F_{0} \times \exp ^{-b_{P U F} \times t}$

$P U F(t)=P U F_{0} \times^{-b_{P U F} \times t}$

where $P U F(t)$ is the plant uptake factor as a function of time and $P U F_{0}$ represents a hypothetical $P U F$ that is the $P U F$ when $t=0$, and $b_{P U F}$ is an equation parameter. Experimental data showed that PUF for grain maize at time close to maturity stage tends to reach a stable minimum value (Molina 2009), thus PUF(t) can be better described as:

$P U F(t)=P U F_{h}+A \times^{-b_{P U F} \times t}$

where $P U F_{h}$ is the PUF at time when the transfer from soil to plant completes (harvest), $\mathrm{A}$ is an equation parameter, and $P U F_{h}+A=\mathrm{PUF}_{0}$, i.e., the theoretical PUF at $t=0$. These equations illustrate the dynamic process of trace element uptake by growing plants and characterize the kinetics of trace element transfer from soils to plants.

Different absorption mechanisms and distribution of trace elements within plants may be described, depending on the element, the plant type, and the phonological stage (Prasad 1997). The model represented by the Eqs. 6-8 was evaluated by Chen et al. (2009b) only for Cd uptake in field-cultivated lettuce (leafy vegetable). Consequently, the model has not been applied to compare different trace elements or tested on a different plant species (e.g., cereals).

\section{Objectives}

We hypothesize that plant uptake of soil borne trace elements is a time-dependent dynamic process, and develop the following field scale experiment and use the outcomes to: i) quantify and characterize $\mathrm{As}, \mathrm{Cd}$, $\mathrm{Cu}$, and $\mathrm{Zn}$ absorption of maize (Zea mays L.) over the growing season, and ii) evaluate the kinetics of trace element uptake process. These elements present different environmental health challenges as they cross the soil-plant inter phase (WHO 2009).

\section{Materials and methods}

Site description

The field experiments were set up at a large scale production farm located in San Pedro $\left(34^{\circ} 01^{\prime} \mathrm{S}\right.$, $\left.71^{\circ} 22^{\prime} W\right)$, Región Metropolitana, central Chile. The average annual rainfall is $350 \mathrm{~mm}$ and average daily temperature was $13.9{ }^{\circ} \mathrm{C}$. The soil is a Mollisol (Mixed, thermic, Ultic Haploxerolls) with high natural fertility and it is typical of the region where maize is intensely cultivated. The site had been under conventional tillage maize cultivation since 1993 and received heavy fertilizer and herbicide applications. The phosphorus $(\mathrm{P})$ fertilizers used over the years had been mono-ammonium phosphate (MAP) and triple superphosphate (TSP) that were the highest in $\mathrm{As}, \mathrm{Cd}, \mathrm{Cu}$, and $\mathrm{Zn}$ contents among fertilizers commonly used in Chilean croplands (Molina et al. 2009). A central pivot irrigation system was employed.

\section{Crop management}

During two following growing seasons, a 0.14-ha area within the production field was selected for the experiment. Grain maize (var. Mycogen 2878) was sown in mid October with $0.75 \mathrm{~m}$ distance between rows and at an average population of 95,000 plants $\mathrm{ha}^{-1}$. Typical cultivation practices were followed. Fertilizers were applied at rates of $400 \mathrm{kgNha}^{-1}$ as urea, $65.5 \mathrm{~kg} \mathrm{P} \mathrm{ha}^{-1}$ as MAP, and $150 \mathrm{kgKha}^{-1}$ as potassium chloride ( $\left.\mathrm{KCl}\right)$. The MAP and $\mathrm{KCl}$, accounting for $7 \%$ of the total $\mathrm{N}$ and $100 \%$ of the total $\mathrm{P}$ and $\mathrm{K}$ fertilizer inputs, were applied at time of planting. The urea was applied in 6 split applications through the central pivot irrigation system. The total irrigation ranged between $650-700 \mathrm{mmha}^{-1}$.

The GDD were calculated according to:

$G D D=\sum_{1}^{n}\left(T_{m}-T_{b}\right)$ 
where $T_{m}$ is the average daily air temperature $\left({ }^{\circ} \mathrm{C}\right), T_{b}$ is the physiological base temperature for maize growth $\left(10{ }^{\circ} \mathrm{C}\right)$, and $n$ is the number of growing days; $\left(T_{m}\right.$ $\left.T_{b}\right)=0{ }^{\circ} \mathrm{C}$ if $\mathrm{T}_{\mathrm{m}}<10^{\circ} \mathrm{C}$ and $\left(T_{m}-\mathrm{T}_{\mathrm{b}}\right)=20{ }^{\circ} \mathrm{C}$ if $T_{m}>$ $30{ }^{\circ} \mathrm{C}$. The crops were harvested toward the end of March when plant growth accumulated between 1,320-1,380 GDD.

Soil and plant sampling and analysis

Above-ground plant biomass samples were taken 6 to 7 times during the course of a growing season. The first sample was taken at plant growth stage of 3-4 leaves. Each time, composite tissue samples consisting of three plants in a row were obtained at three randomly selected locations in the experimental plot. The plant material was separated into two portions namely stem + leaves and ears, washed with a diluted $\mathrm{HCl}$ solution, rinsed with double-distilled water, and dried at $65^{\circ}$ until reaching constant weight. The dried plant material was then ground to pass a screen with $0.5-\mathrm{mm}$ openings and sub-sampled. Aliquots of $0.5 \pm 0.001 \mathrm{~g}$ ground plant tissue were microwave digested in Teflon pressure bomb with $4 \mathrm{ml}$ $\mathrm{HNO}_{3}(65 \%), 4 \mathrm{ml} \mathrm{H}_{2} \mathrm{O}_{2}(30 \%)$ and $2 \mathrm{ml} \mathrm{de}-$ ionized water according to USEPA Method 3052 (USEPA 1996). The Cd content of the digests was determined by graphite furnace-atomic absorption spectroscopy and As content of the digests was determined by hydride-generation atomic absorption spectroscopy. The copper and $\mathrm{Zn}$ contents were determined by inductively coupled plasmaoptical emission spectroscopy.

Composite soil samples were taken from the plow layer (0-25 cm depth), passed through a screen with 2-mm openings, and air-dried. The samples were characterized according to procedures outlined in the Methods of Soil Analysis of American Society of Agronomy (Page et al. 1982): determinations of soil texture by the hydrometer method, $\mathrm{pH}$ and electrical conductivity in extracts of $1: 2.5(\mathrm{w} / \mathrm{v})$ soil to water ratio, organic carbon by chromic acid digestion, exchangeable bases by equilibrating with ammonium acetate at $\mathrm{pH}=7.0$, and $\mathrm{CaCO}_{3}$ equivalent by the gravimetric method (Table 1). At the beginning of each season, soil samples (three replicates) were taken and the soil solution concentration $\left(\mathrm{C}_{\mathrm{ss}}\right)$ of trace elements was
Table 1 Selected properties of the soil

\begin{tabular}{ll}
\hline Parameter & Measurement \\
\hline Soil Texture & Clay loam \\
Sand & $35.0(\%)$ \\
Silt & $25.2(\%)$ \\
Clay & $39.8(\%)$ \\
$\mathrm{pH}_{\mathrm{H} 2 \mathrm{O}}$ & 5.6 \\
Electrical conductivity & $0.14\left(\mathrm{dS} \mathrm{m}^{-1}\right)$ \\
$\mathrm{Sum}_{\mathrm{a}}$ of bases & $16.8\left(\mathrm{cmol} \mathrm{kg}^{-1}\right)$ \\
Organic matter & $2.9(\%)$ \\
$\mathrm{CaCO}_{3}$ equivalent & $1.8(\%)$ \\
\hline
\end{tabular}

${ }^{\text {a }}$ According to USDA soil classification

estimated by equilibrating soil and water mixtures (soil-to-water ratio of 1:0.5) for $48 \mathrm{~h}$ in an orbital shaker rotating at $40 \mathrm{rpm}$ (Chen et al. 2007). After the equilibrium, samples were centrifuged and filtered. The concentration of $\mathrm{As}, \mathrm{Cd}, \mathrm{Cu}$ and $\mathrm{Zn}$ were determined on the solutions by the same analytical methods as the plant tissue digests.

Quality control and assurance

Quality of analysis was assured by comparison with certified standard reference materials SRM 2709 (soil), SRM 1547 (peach leaves) and SRM 1640 (water) from the US National Institute of Standards and Technology (NIST). The analysis was repeated if deviation was $>10 \%$. To ensure the precision of the analysis, each sample was digested and analyzed in duplicate. The concentrations of the replicates were compared and the analysis was repeated if the replicate difference was $>10 \%$. Spiked samples were also used to establish if matrix interference was causing amplification or decrease in sample response.

Data analysis

The experimental data were fitted to the model equations using a non-linear regression procedure using SigmaPlot 10.0 (Systat Software Inc.). Statistical comparisons between seasons and among different elements were done by comparing the confidence intervals (CI, $95 \%$ probability) of the equations' parameters as estimated by the nonlinear regression procedure. 
Table 2 Trace element contents (mean concentration \pm standard deviation) and partition coefficients $\left(\mathrm{K}_{\mathrm{d}}\right)$ of the experimental soil

\begin{tabular}{llll}
\hline Element & Total, $C_{\text {total }},\left(\mathrm{mgkg}^{-1}\right)$ & Solution, $C_{\text {sol, }}\left(\mathrm{mgL}^{-1}\right)$ & $\mathrm{K}_{\mathrm{d}}\left(\mathrm{Lkg}^{-1}\right)$ \\
\hline As & $9.1 \pm 1.0$ & $1.74 \times 10^{-3} \pm 1.8 \times 10^{-4}$ & 5,230 \\
$\mathrm{Cd}$ & $0.27 \pm 0.026$ & $2.19 \times 10^{-4} \pm 5.6 \times 10^{-5}$ & 1,230 \\
$\mathrm{Cu}$ & $32.3 \pm 2.4$ & $0.229 \pm 0.043$ & 141 \\
$\mathrm{Zn}$ & $65.4 \pm 3.0$ & $0.255 \pm 0.052$ & 286 \\
\hline
\end{tabular}

\section{Results}

Trace element contents of the soil

The total As, $\mathrm{Cd}, \mathrm{Cu}$, and $\mathrm{Zn}$ contents of the soil (Table 2), $C_{\text {total }}$, were well within the concentration range for soils under agricultural cultivations around the world (Kabata-Pendias and Pendias 2001). Trace element concentration of the soil solution, $C_{s s}$, representing the extent of readily plant available As, $\mathrm{Cd}$, $\mathrm{Cu}$, and $\mathrm{Zn}$ of the soil, were a small fraction of the respective total amount (Table 2) and the kinetics of their dissolution from solid phases would expected to be slow (Chen et al. 2006). The Cd and As in soil solution phase represented less than $0.042 \%$ and the $\mathrm{Cu}$ and $\mathrm{Zn}$ in soil solution phase represented less than $0.36 \%$ of their respective total contents.

For all trace elements, no significant differences $(p<0.01)$ were recorded for $\mathrm{C}_{\mathrm{ss}}$ when compared at the beginning of the two consecutive seasons. The same was valid for soil $\mathrm{pH}$ and EC (data not shown). Even when it is well recognized that $\mathrm{C}_{\mathrm{ss}}$ in the rizosphere may change throughout the season due to the influence of roots on soil $\mathrm{pH}$, organic acids concentration, and water content (Gobran et al. 2001), the bulk soil solution concentration is less sensitive to such effects. Chen et al. (2009b) observed that bulk $\mathrm{Cd}-\mathrm{C}_{\mathrm{ss}}$ slightly varied over the growing season, with no significant effect of time in a soil cultivated with lettuce. Thus, for modeling purposes, the bulk $\mathrm{C}_{\mathrm{ss}}$ could be considered constant.

The $K_{d}$ values were comparable in magnitude to those of agricultural soils reported elsewhere (Chen et al. 2009a) and were considerably lower than those of the soils contaminated by anthropogenic activities (Sauvé et al. 2000).

Biomass production and trace element uptake

The above-ground biomass production grew according to Eq. 5 in which $R^{2}=0.99$. The equation parameters obtained through data of the first and second growing seasons were not significantly different, thus were pooled to obtain the equation parameters shown in Eq. 11 that:

$B M(t)=\frac{B M_{\max }}{1+\exp ^{-\frac{(t-795)}{187}}}$

For maize, the time (GDD) to reach $50 \%$ maximum biomass, $t_{B M 50}$, was $795{ }^{\circ} \mathrm{C}$-day and the exponential biomass growth rate $\left(\mathrm{GDD}^{-1}\right), b_{B M}$, was $187^{\circ} \mathrm{C}$-day ${ }^{-1}$. Based on Eq. 11, the biomass yield of maize can be tracked and the maximum biomass yield can be obtained by simply measuring the biomass at time $t$ during the course of a growing season and set $t$ to the targeted harvesting growing degree days of the plant.

When maize plants were harvested, the concentrations of As and $\mathrm{Cd}$ in the shoot + leaves portion were approximately one order of magnitude higher than those of the ear portion while the concentrations of $\mathrm{Cu}$ and $\mathrm{Zn}$ in shoot + leaves portion were comparable to those of the ear portion (Table 3). In Table 3, the concentration range over the growing season was temporally classified to depict the gradually decreased trace element concentrations of plant tissue over time. The element concentrations of both the shoot + leaves and ears portions of maize were the highest at the early stage of their formations and decreased over the time until shortly before harvesting.

Table 3 Trace elements in maize plants: Concentration range $\left(\mathrm{mgkg}^{-1}\right)$ from beginning (3-4 leaves growth stage) to end of the growing season

\begin{tabular}{lllll}
\hline Plant part & $\mathrm{As}$ & $\mathrm{Cd}$ & $\mathrm{Cu}$ & $\mathrm{Zn}$ \\
\hline $\begin{array}{c}\text { Shoot }+ \\
\text { leaves }\end{array}$ & $0.053-0.024$ & $0.045-0.019$ & $9.6-2.9$ & $38.3-14.1$ \\
Corn ears & $0.016-<0.009^{\mathrm{a}}$ & $0.016-<0.005^{\mathrm{a}}$ & $3.6-1.6$ & $32.5-15.0$ \\
\hline
\end{tabular}

${ }^{\mathrm{a}}$ Limit of detection 
The trace element uptake rate (Fig. 1), $U(t)$, followed the same pattern of the cumulative
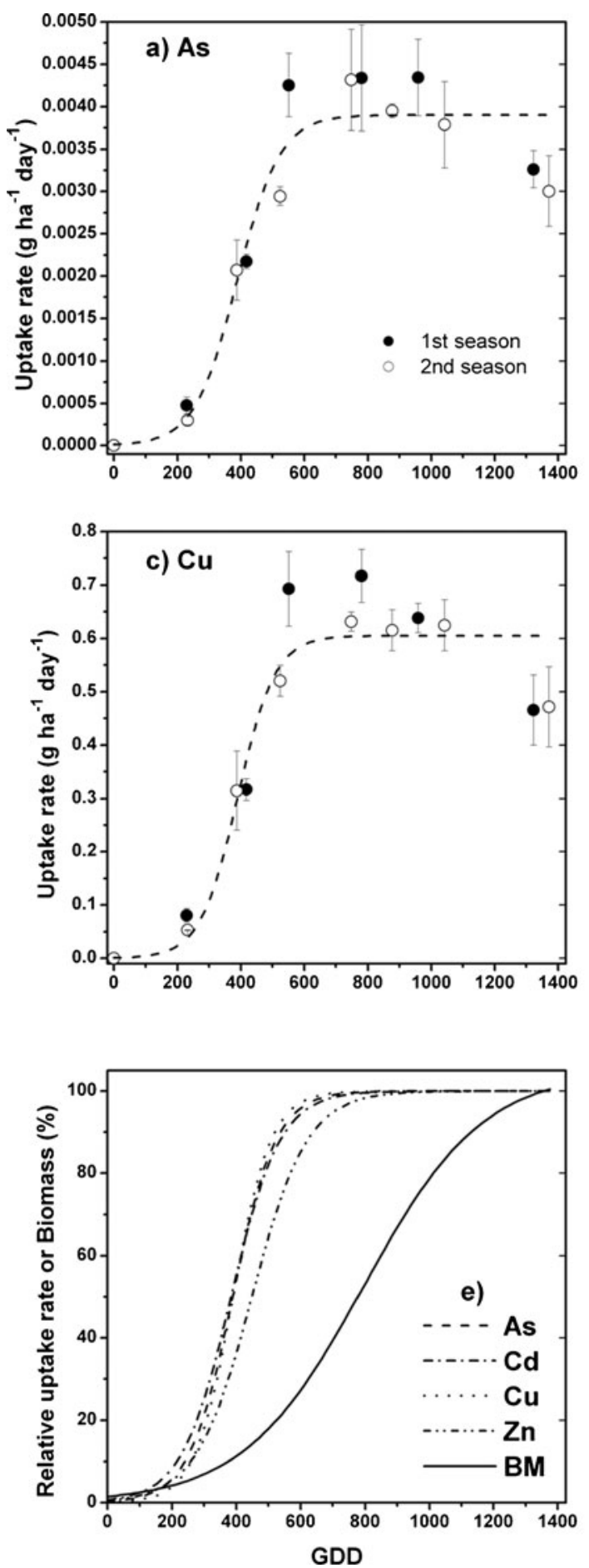

Fig. 1 Trace element cumulative uptake rate (a-b), and relative biomass accumulation (BM) and element uptake (e) of maize plants as a function of growing degree days $(G D D)$ showing increase of plant biomass and fitted the model described by Eq. 6 (Table 4). The maximum
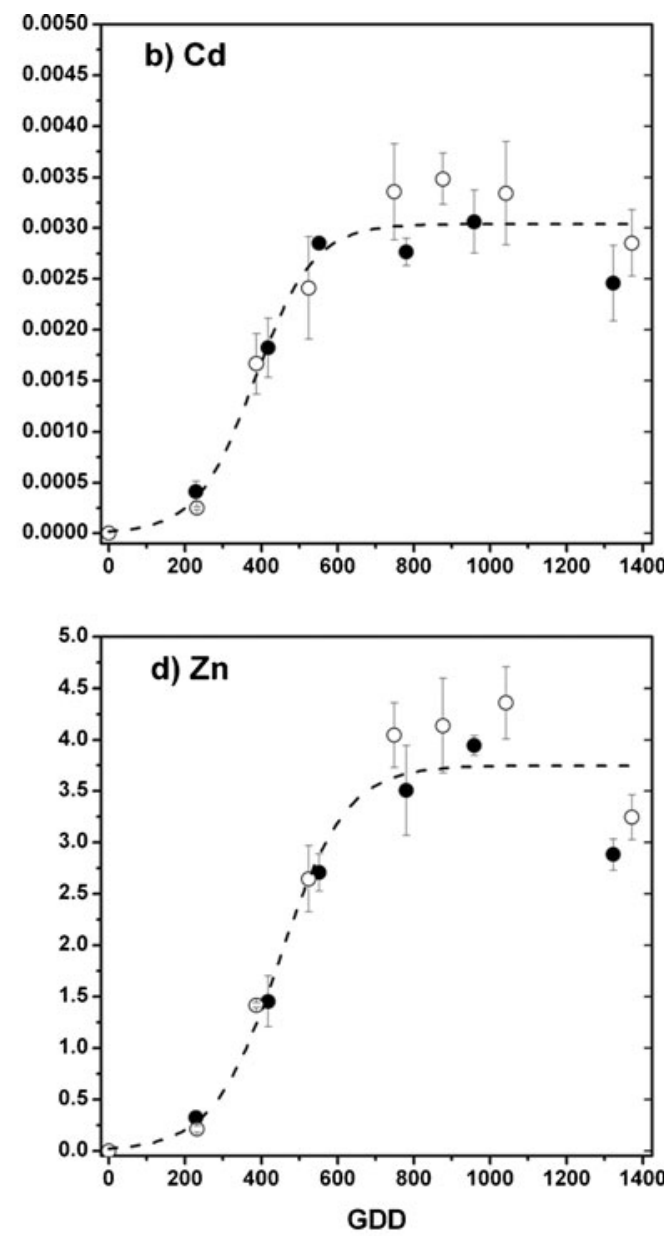

mean and standard deviation of experimental data and depictions according to Eqs. 5 and 6 
Table 4 Trace element uptake kinetics (Eq. 6) for maize plants. $U_{\max }$ maximum cumulative uptake rate, $\mathrm{t}_{\mathrm{U} 50}$ time to reach a $50 \%$ of $\mathrm{U}_{\max }, b_{U}$ reciprocal of the uptake rate, GDD growing degree days. \pm indicates confidence interval $(95 \%)$

\begin{tabular}{lllll}
\hline Kinetic parameters & As & Cd & $\mathrm{Cu}$ & $\mathrm{Zn}$ \\
\hline$U_{\max }\left(\mathrm{gha}^{-1} \mathrm{day}^{-1}\right)$ & $3.9 \times 10^{-3} \pm 0.3 \times 10^{-3}$ & $3.0 \times 10^{-3} \pm 0.1 \times 10^{-3}$ & $0.61 \pm 0.03$ & $3.75 \pm 0.17$ \\
$t_{U 50}(G D D)$ & $389 \pm 25$ & $384 \pm 20$ & $390 \pm 24$ & $449 \pm 24$ \\
$b_{U}(G D D)$ & $67.5 \pm 23.8$ & $76.7 \pm 18.0$ & $59.1 \pm 24.5$ & $86.6 \pm 23.4$ \\
$\mathrm{R}^{2}$ & 0.917 & 0.950 & 0.906 & 0.940 \\
\hline
\end{tabular}

${ }^{\text {a }}$ Calculated according to Eq. 8

uptake rate, $U_{\max }$, were $3.9 \times 10^{-3}, 3.0 \times 10^{-3}, 0.61$, and $3.8 \mathrm{gha}^{-1} \mathrm{day}^{-1}$ for $\mathrm{As}, \mathrm{Cd}, \mathrm{Cu}$, and $\mathrm{Zn}$, respectively. The patterns of $U(t)$ vs. $t$ (GDD) plots for $\mathrm{As}, \mathrm{Cd}, \mathrm{Cu}$, and $\mathrm{Zn}$ were virtually the same. For all of the elements, the $U(t)$ exhibited a notable dip at the time of harvest, comparing to that of the previous sampling date (Fig. 1a through d). The discrepancy might be attributed to the loss of basal leaves as the plants drying out resulting to an underestimation of biomass thus the maximum uptake rate at harvest, $U_{\max }$. During the seedling stage from 0 to 200 degree days, the plant uptake of trace elements was low due to the limited root density. The trace elements started to accumulate in the plant tissue in the exponential manner according to the biomass growth from 200 to 600 degree days. Afterwards, the cumulative uptake rate leveled off and reached the $U_{\max }$. For As, $\mathrm{Cd}$, and $\mathrm{Cu}$, the $U_{\max }$ was reached at 600 to 700 degree days during the R1 anthesis (silking) stage of plants. The $U_{\max }$ for $\mathrm{Zn}$ was reached approximately 7 days later at 700 to 800 degree days when the plants were between the R2 blister and R3 kernel stages coinciding with the $t_{B M 50}$ for cumulative biomass (Eq. 11).

Plant uptake factor

The PUF of As, Cd, $\mathrm{Cu}$, and $\mathrm{Zn}$ decreased exponentially over the growing season (Fig. 2) according to Eq. 9 (Table 5) showing that biomass accumulation is faster than the root absorption and transfer of the elements to the above-ground biomass of plants (mass dilution effect). When the time was normalized in terms of $G D D$, the PUF remained fairly consistent over the two growing seasons and was well described by this first order reaction model (Fig. 2). The PUF decreased approximately 7.2, 6.3, 7.6, and 3.6 times for As, $\mathrm{Cd}, \mathrm{Cu}$ and $\mathrm{Zn}$, respectively, from the early growing stages to harvest time. From seeding to the R2 stage (700 GDD), the PUF followed the sequence: $\mathrm{Cd}>\mathrm{Zn}>\mathrm{Cu}>\mathrm{As}$. From the R2 stage, when the maximum uptake rate for $\mathrm{Zn}$ was reached, the sequence was: $\mathrm{Cd} \geq \mathrm{Zn}>\mathrm{Cu} \geq$ As (Fig. 2e, Table 5).

\section{Discussion}

Trace element uptake

The concentrations of $\mathrm{As}, \mathrm{Cd}$, and $\mathrm{Cu}$ in the shoot + leaves portion were consistently higher than those in the ear portion throughout the season, indicating that there were physiological barriers that hinder the passage of these elements from stem + leaves to the ears, especially for As and $\mathrm{Cd}$. In the case of $\mathrm{Zn}$, there appeared to have a remobilization of this element from other parts of plants to the ears (Petruzzelli et al. 1989). At harvest, the percentage of trace elements in the ears, in relation to the total uptake, showed that $\mathrm{Zn}>\mathrm{Cu}>\mathrm{Cd}>\mathrm{As}$ (Fig. 3, Table 6) in that As and $\mathrm{Cd}$ contents of the ears represented less than $9 \%$ and $20 \%$ of the total plant uptake, respectively. The trace metals that play a role as micronutrients, $\mathrm{Cu}$ and $\mathrm{Zn}$, in the stem + leaves and ears portions were approximately 45 to $55 \%$ splits. Maize plants extracted small amounts of trace elements from soils. In spite of the large biomass production, the total uptake of trace elements by maize averaged $0.52,0.43,77.1$, and $520 \mathrm{gha}^{-1}$ year $^{-1}$ for $\mathrm{As}, \mathrm{Cd}, \mathrm{Cu}$, and $\mathrm{Zn}$, respectively (Table 6). It is interesting to note that for $\mathrm{As}$ and $\mathrm{Cd}$ these amounts are considerably lower than their annual inputs through $\mathrm{P}$ fertilizer applications for typical 

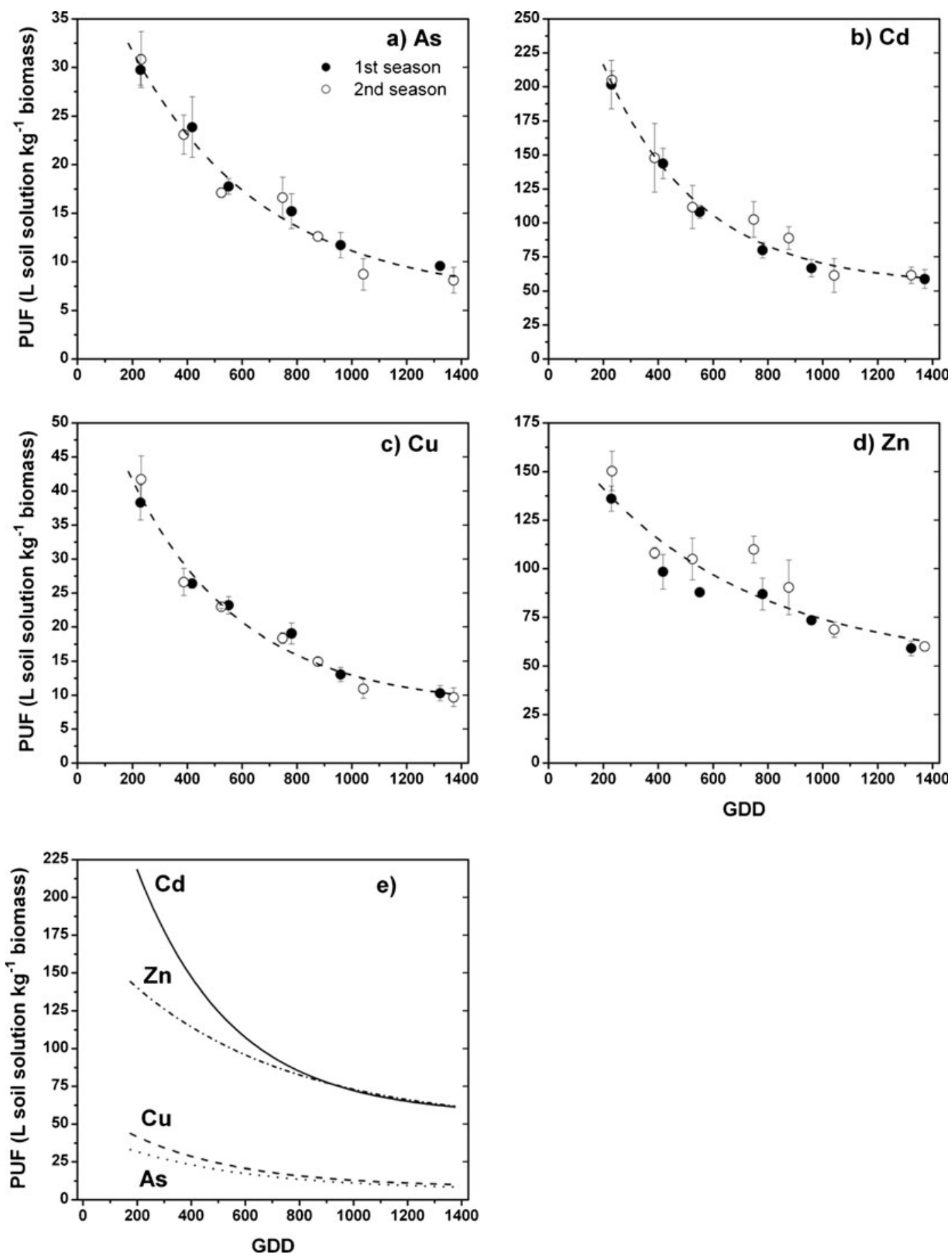

Fig. 2 Plant uptake factor (PUF) as function of growing degree days $(G D D)$ for maize plants showing mean and standard deviation of experimental data and depictions according to Eq. 9

high-yield maize production system in Chile that fell in the range of 3.6 to $6.4 \mathrm{~g} \mathrm{As} \mathrm{ha}^{-1}$ and 1.2 to $17.4 \mathrm{~g} \mathrm{Cd} \mathrm{ha}^{-1}$ (Molina et al. 2009). Potentially, the harmful trace elements may accumulate in the cropland soils under long-term cultivation. This situation is not always valid for $\mathrm{Cu}$ and $\mathrm{Zn}$, whose balances in a maize-cultivated soil (soil accumulation), can be positive or negative strongly 
Table 5 Kinetics of trace element plant uptake factors, PUF (Eq. 9), for maize plants. $P U F_{0}$ theoretical PUF at $\mathrm{t}=0, P U F_{h}=$ PUF at time close to harvest. \pm indicates confidence interval (95\%)

\begin{tabular}{|c|c|c|c|c|}
\hline Kinetic parameters & As & $\mathrm{Cd}$ & $\mathrm{Cu}$ & $\mathrm{Zn}$ \\
\hline $\begin{array}{l}P U F_{0}=P U F_{h}+A \\
\quad\left(\mathrm{~L} \text { soil solution } \mathrm{kg}^{-1} \mathrm{BM}\right)\end{array}$ & $44.6 \pm 8.5$ & $341 \pm 28$ & $62.8 \pm 11.3$ & $177 \pm 55.9$ \\
\hline $\begin{array}{l}P U F_{h}(\mathrm{~L} \text { soil } \\
\left.\quad \text { solution } \mathrm{kg}^{-1} \mathrm{BM}\right)\end{array}$ & $6.3 \pm 3.7$ & $53.8 \pm 6.4$ & $8.3 \pm 3.5$ & $49.8 \pm 22.7$ \\
\hline $\mathrm{b}_{\mathrm{PUF}}(\mathrm{GDD})$ & $2.06 \times 10^{-3} \pm 0.74 \times 10^{-3}$ & $2.86 \times 10^{-3} \pm 0.71 \times 10^{-3}$ & $2.46 \times 10^{-3} \pm 0.74 \times 10^{-3}$ & $1.66 \times 10^{-3} \pm 0.91 \times 10^{-3}$ \\
\hline $\mathrm{R}^{2}$ & 0.973 & 0.982 & 0.977 & 0.849 \\
\hline
\end{tabular}

depending on the trace element content of applied fertilizers (Molina 2009).

Increasing uptake rates of $\mathrm{As}, \mathrm{Cd}, \mathrm{Cu}$, and $\mathrm{Zn}$ from soils took place primarily in the early half of the growing season when the biomass accumulation was still less than $50 \%$ of the maximum harvested biomass (Fig. 1). The uptake rate then reach a stable maximum value $\left(U_{\max }\right)$ which is governed by the increment of biomass and a lower accumulation of trace element per unit of plant biomass. The absorbed trace elements would then be redistributed inside the increasing plant tissue biomass during the later stage of growth. Even when As and $\mathrm{Cd}$ have no relevance in terms of plant nutrition, their uptake patterns are similar to $\mathrm{Cu}$ and $\mathrm{Zn}$.

Plant uptake factor

The drop of the PUF has been attributed to a greater root competition, decrease in the activity of both mature and young roots, and/or greater proportion of lower-activity mature roots in relation to younger roots as the plants develop to maturity (Barber 1995; Mengel and Barber 1974a). It was early demonstrated that the root density in maize plants tends to decrease from flowering to maturity stage (Mengel and Barber 1974b). Consequentially, the element uptake potential also decreases along the season. Even when no significant differences were noted between the kinetics of the drop of the PUF, represented by $\mathrm{b}_{\mathrm{PUF}}$, this parameter was lower for $\mathrm{Zn}$ in comparison to the other metals (Table 5) indicating a relative lower decrease of Zn-PUF along the season in comparison to the other elements. Because of the greater transfer to ear biomass (Fig. 3), the active absorption of $\mathrm{Zn}$ is kept over time and the absorption activity is higher in relation the other three elements. These results agree with those reported by Karlen et al. (1988), who observed that more $\mathrm{Zn}$ was accumulated during grain fill than that was
Fig. 3 Trace element distribution in harvested maize plants

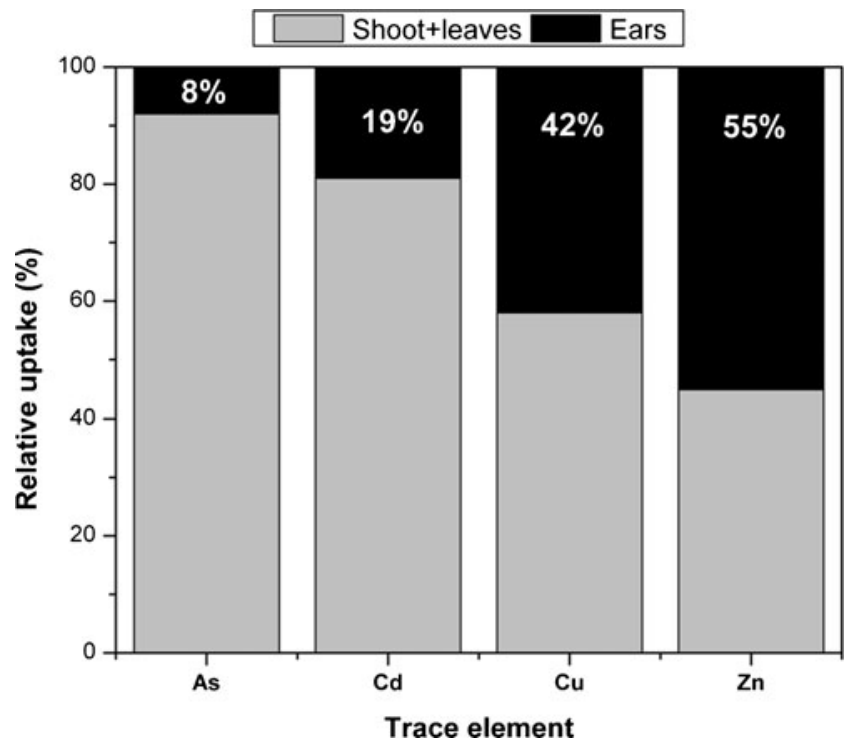


Table 6 Trace elements in maize plants: Total uptake $\left(\mathrm{gha}^{-1}\right)$ at harvest time.

Mean \pm standard deviation

\begin{tabular}{lllll}
\hline Plant part & As & Cd & Cu & Zn \\
\hline Shoot + leaves & $0.470 \pm 0.029$ & $0.360 \pm 0.024$ & $45.2 \pm 4.8$ & $236 \pm 26$ \\
Corn ears & $0.040 \pm 0.023$ & $0.080 \pm 0.022$ & $32.2 \pm 4.1$ & $286 \pm 17$ \\
Whole plant & $0.520 \pm 0.030$ & $0.430 \pm 0.046$ & $77.1 \pm 5.0$ & $520 \pm 43$ \\
\hline
\end{tabular}

lost from vegetative parts, which indicated that the ability of maize roots to uptake $\mathrm{Zn}$ is kept along the growing season.

The absorption of $\mathrm{As}, \mathrm{Cu}$, and $\mathrm{Zn}$ in plants is mainly active (Abedin et al. 2002 Bowen 1987; Reid 2001). In the case of $\mathrm{Cd}$ both passive and active mechanisms can be involved (Harris and Taylor 2004; Smeyers-Verbeke et al. 1978). At the beginning of the vegetative stage $\mathrm{Cd}$ showed a bioavailability notably higher in comparison to the other elements. At the end of the season, the availability of $\mathrm{Cd}$, as assessed by the PUF, is comparable to that of $\mathrm{Zn}$ (Fig. 2; Table 5). According to Reid (2001), the membrane cation transporters of roots have a wide range of substrates which allow the absorption of non-essential elements, like $\mathrm{Cd}$, through the channels for other cations with lower selectivity such as $\mathrm{Ca}, \mathrm{Cu}, \mathrm{Fe}$, and $\mathrm{Zn}$. In our experiment, As was the element with lowest bioavailability. The transfer of As from roots to above-ground biomass is limited in plants (Kabata-Pendias and Pendias 2001). In addition, the soil in this study has received the application of high doses of $\mathrm{P}$ fertilizers, and the As absorption by roots may be limited in presence of high levels of available $\mathrm{P}$ because of the competition of arsenate and phosphate (Gulz et al. 2005), the dominating forms of theses anions under aerated soil conditions.

Conceptually, PUF illustrates the partition of a trace element between those present in soil solution and those taking up by growing plants. In this regard, the PUF should denote the partition at the end of the soil-to-plant transferring process, $\mathrm{PUF}_{\mathrm{h}}$, i.e., when the plants matured. Therefore, for a specific element, the $\mathrm{PUF}_{\mathrm{h}}$ may be written in terms of the kinetic parameters of the uptake process as:

$P U F_{h}=\frac{\frac{U_{\max }}{B M_{\max }}}{C_{S S}} \times d a y s$

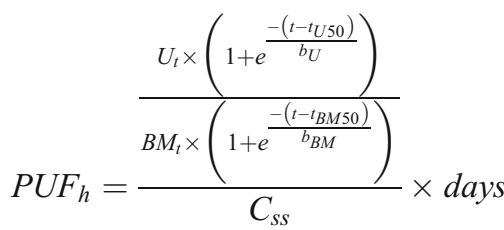

in which, days indicate the number of days to harvest.

Judging the data presented in Fig. 2 and Table 5, the PUF of $\mathrm{Cd}$ and $\mathrm{Zn}$ were at least one order of magnitude greater that those of As and $\mathrm{Cu}$. On a per-unit-soil solution element basis, $\mathrm{Cd}$ and $\mathrm{Zn}$ would be more susceptible to the soilto-plant transfer than $\mathrm{As}$ and $\mathrm{Cu}$.

In our experiment and in a previously reported work (Chen et al. 2009b)2009b), the trace element uptake rates were related to its soil solution concentration. The kinetic parameters of the model accounted for the change of the plants' ability to uptake the elements during the growing season and allowed comparisons among them. It is well recognized that the $\mathrm{pH}$, the presence of competing cations and complexing agents (i.e., soluble organic matter) in the soil solution can influence the uptake rates, making more difficult and complex the predictions of metal bioavailability. Protons and cations compete for the absorption sites at root surfaces, while complexation changes the bioavailability by competing with the plant roots for the metal (Hough et al. 2005; Kalis et al. 2006; Kunhikrishnan et al. 2011; Perriguey et al. 2008). Additionally, it has been demonstrated that trace element free concentration or activity does not necessarily improve the prediction of metal uptake by plants when compared with data obtained from total soil solution concentration (e.g., Hough et al. 2005). On this regard, the model used in this work needs to be tested on different soil types and conditions to evaluate its applicability in a wide range of agro-ecosystems, and, if necessary, analytical determinations and model calculations could be incorporated to estimate, in the soil solution, the metal speciation and to include the mentioned 
soil solution factors. However, once the best indicator of metal bioavailability is defined, the model implementation and parametization remains the same.

\section{Conclusions}

We used the maize plants grown in production fields to illustrate and compare the uptake dynamics of soil borne trace elements namely $\mathrm{As}, \mathrm{Cd}$, $\mathrm{Cu}$ and $\mathrm{Zn}$.

1. The kinetic parameters of the uptake process, maximum cumulative uptake rate, $U_{\max }$, time to reach $50 \%$ of $U_{\max }, t_{U 50}$, and reciprocal of the uptake rates of, $b_{U}$ when followed throughout the season in terms of the plant's growing degree days remained constant between seasons and was element specific.

2. Increasing cumulative uptake rate of $\mathrm{As}, \mathrm{Cd}, \mathrm{Cu}$, and $\mathrm{Zn}$ from soils took place primarily in the early half of the growing season when the biomass accumulation was still less than $50 \%$ of the maximum biomass harvested. The uptake rate then tend to stabilize and the absorbed trace elements were redistributed in later half of the growing season as the biomass continued to accumulate.

3. The plant uptake factor, $P U F$, which denote the partition of trace elements between the soil solution and plant phases, decreased following a firstorder kinetics along the growing period and did not show any significant difference between seasons. This bioaccumulation index may be estimated according to the kinetics parameters of the trace element uptake process.

4. On a per-unit-soil solution element basis, $\mathrm{Cd}$ and $\mathrm{Zn}$ would be more susceptible to the soil-to-plant transfer than $\mathrm{As}$ and $\mathrm{Cu}$.

Acknowledgments This work was supported in part by FONDECYT (Fund for the development of science and technology) under project number 1070116 (Chile). Authors thank Woody Smith for his assistance in trace element determination for soil and plant samples. Mauricio Molina would like to thank Mr. Francisco Correa for allowing soil and plant sampling and for providing crop management information, and acknowledge PUC-MECESUP (Pontificia Universidad Católica de ChileProgram of Improvement of Superior Education Quality)
Doctoral Scholarship and PUC-VRAID (Academic ViceRectory for Research and Development) Scholarship for international stays.

\section{References}

Abedin M, Feldmann J, Meharg A (2002) Uptake kinetics of arsenic species in rice plants. Plant Physiol 128:1120 1128

Barber SA (1995) Soil nutrient bioavailability: a mechanistic approach. Wiley and Sons, New York, USA

BassiriRad H, Prior S, Norby R, Rogers H (1999) A field method of determining $\mathrm{NH}_{4}{ }^{+}$and $\mathrm{NO}_{3}{ }^{-}$uptake kinetics in intact roots: effect of $\mathrm{CO}_{2}$ enrichment on trees and crop species. Plant Soil 217:195-204

Bowen JE (1987) Physiology of genotypic differences in zinc and copper uptake in rice and tomato. Plant Soil 99:115125

Chang AC, Page AL (2000) Trace element slowly accumulating/depleting in soils. Calif Agric 54:49-55

Chen W, Chang AC, Wu L, Page AL (2006) Modeling dynamic sorption of $\mathrm{Cd}$ in cropland soils. Vad Zone J 5:1216-1221

Chen W, Chang AC, Wu L, Lianquing L, Kwon SI, Page AL (2007) Probability distribution of cadmium partitioning coefficients of cropland soils. Soil Sci 172:132-140

Chen W, Li L, Chang AC, Wu L, Kwon SI, Bottoms R (2008) Modeling uptake kinetics of cadmium by field-grown lettuce. Environ Pollut 152:147-152

Chen W, Li L, Chang AC, Wu L, Chaney RL, Smith R, Ajwa H (2009a) Characterizing the solid-solution partition coefficient and plant uptake factor of $\mathrm{As}, \mathrm{Cd}$, and $\mathrm{Pb}$ in California croplands. Agric Ecosyst Environ 129:212-220

Chen W, Li L, Chang AC, Wu L, Kwon S, Bottoms R (2009b) Cadmium uptake by lettuce in fields treated with cadmiumspikeled phosphorus fertilizers. Commun Soil Sci Plant Anal 40:1124-1137

Dach J, Starmans D (2005) Heavy metals balance in Polish and Dutch agronomy: actual state and previsions for the future. Agric Ecosyst Environ 107:309-316

Darrah P, Staunton S (2000) A mathematical model of root uptake of cations incorporating root turnover, distribution within the plant, and recycling of absorbed species. Eur J Soil Sci 51:643-653

Gerritse RG, Van Driel W, Smilde KW, Van Luit B (1983) Uptake of heavy metals by crops in relation to their concentration in soil solution. Plant Soil 75:393-404

Gobran G, Lombi E, Walter W (2001) Trace elements in the rizosphere. CRC Press, Boca Raton

Gulz PA, Gupta S, Schulin R (2005) Arsenic uptake of common plants from contaminated soils. Plant Soil 272:337-347

Guttormsen G, Singh BR, Jeng AS (1995) Cadmium concentration in vegetable crops grown in a sandy soil as affected by $\mathrm{Cd}$ levels in fertilizer and soil $\mathrm{pH}$. Fert Res 41:27-32

Habbas MHH, Meharg AA (2008) Arsenate, arsenite, and dimethyl arsenic acid (DMA) uptake and tolerance in maize (Zea maiz L.). Plant Soil 304:277-289

Harris NS, Taylor GJ (2004) Cadmium uptake and translocation in seedlings of near isogenic of durum wheat that differs in grain cadmium accumulation. Plant Biol 4:4 
Hough RL, Tye AM, Crout NMJ, McGrath SP, Zhang H, Young SD (2005) Evaluating a 'free ion activity model' applied to metal uptake by Lolium perenne L. grown in contaminated soils. Plant Soil 270:1-12

Huang RQ, Gao FS, Wang WL, Staunton S, Wang G (2006) Soil arsenic availability and the transfer of arsenic to crops in suburban areas in Fujian Province, southeast China. Sci Total Environ 368:531-541

Kabata-Pendias A, Pendias H (2001) Trace elements in soils and plants, 3rd edn. CRC Press, Boca Raton

Kalis E, Themminghoff E, Weng L, Van Riemsdijk K (2006) Effect humic acids and competing cations on metal uptake by Lolium perenne L. Environ Toxicol Chem 25:702-711

Karlen DL, Flannery LL, Sadler EJ (1988) Aerial accumulation and partitioning of nutrients by maize. Agron J 80:232-242

Kunhikrishnan A, Bolan N, Naidu R (2011) Availability of copper in the presence of recycled water sources. Plant Soil 348:425-438

Lehoczky E, Kiss Z, Németh T (2006) Study of the transfer coefficient of cadmium and lead in ryegrass and lettuce. Commun Soil Sci Plant Anal 37:2531-2539

Lorenz SE, Hamon RE, Holm PE, Domingues HC, Sequeira SM, Christensen TH, McGrath SP (1997) Cadmium and zinc in plant and soil solutions from contaminated soils. Plant Soil 189:21-31

Mengel DB, Barber SA (1974a) Rate of nutrient uptake per unit of maize root under field conditions. Agron J 66:399-402

Mengel DB, Barber SA (1974b) Development and distribution of maize root system under field conditions. Agron J 66:341-344

Minnich MM, McBride MB, Chaney RL (1987) Copper activity in soil solution: II. Relation to copper accumulation in snapbeans. Soil Sci Soc Am J 51:573-578

Molina MA (2009) Fate of trace elements incorporated into cultivated soils trough fertilizer applications: Absorption by maize (Zea mays L.) plants, dynamics in soils, and long-term modeling. PhD Thesis, Faculty of Agronomy and Forestry, Pontificia Universidad Católica de Chile, Santiago, Chile.

Molina M, Aburto F, Calderón R, Cazanga M, Escudey M (2009) Trace element composition of selected fertilizers used in Chile: phosphorus fertilizers as a source of long-term soil contamination. Soil Sediment Contam 18:497-511

Mullins G, Sommers L (1986) Cadmium and Zinc influx characteristics of intact maize (Zea maiz L.) seedlings. Plant Soil 96:153-164

Nicholson F, Smith S, Alloway B, Carlton-Smith C, Chambers B (2003) An inventory of heavy metals inputs to agricultural soils in England and Wales. Sci Total Environ 311:205-219
Page AL, Miller RH, Keeney DR, eds (1982) Methods of soil analysis. Part 2-Chemical and microbiological properties, $2^{\text {nd }}$ ed. Agronomy series $n^{\circ}$, American Society of Agronomy, Madison, WI, USA.

Parker D, Channey L, Norvell W (1995) Chemical equilibrium models. Applications to plant nutrition research. In:Loeppert R, Schawb A, Golberg S (eds) Chemical equilibrium and reactions models. Special publication 42, Soil Science Society of America, Madison, WI, USA, pp 163-200.

Perriguey J, Sterckeman R, Morel JL (2008) Effect of rhizosphere and plant-related factors on the Cd ptake by maize (Zea mays L.). Environ Exp Bot 63:333-341

Petruzzelli G, Lubrano L, Guidi G (1989) Uptake by maize and chemical extractability of heavy metals from a four year compost treated soil. Plant Soil 116:23-27

Pierzynski G, Sims J, Vance G (2005) Soils and environmental quality, 3rd edn. CRC press, Boca Raton

Prasad MNV (1997) Plant ecophysiology, 1st edn. John Wiley \& Sons, USA

Reid RJ (2001) Mechanisms of micronutrient uptake by plants. Aust J Plant Physiol 28:659-666

Sauvé S, Hendershot W, Allen H (2000) Solid-solution partitioning of metals in contaminated soils: dependence on $\mathrm{pH}$, total metal burden, and organic matter. Environ Sci Technol 34:1125-1131

Silberbush M, Ben-Asher J, Ephrath J (2005) A Model for nutrient and water flow and their uptake by plants grown in a soilless culture. Plant Soil 271:309-319

Smeyers-Verbeke J, de Graeve M, Francois M, de Jaegere R (1978) Cadmium uptake by intact wheat plants. Plant Cell Environ 1:291-296

Soriano MA, Fereres E (2003) Use of crops for phytoremediation of polluted soils following a toxic flood from a mine spill. Plant Soil 256:253-264

Steingrobe B, Schenk M (1994) A model relating the maximum nitrate influx of lettuce (Lactuca sativa L.) to the growth of roots and shoots. Plant Soil 162:249-257

Tudoreanu L, Phillips CJ (2004) Modeling cadmium uptake and accumulation in plants. Adv Agron 84:121-157

USEPA (1996) Method 3052: microwave assisted acid digestion of siliceous and organically based matrices. U.S. Environmental Protection Agency, Washington (DC), USA. http:// www.epa.gov/epaoswer/hazwaste/test/3_series.htm. Accessed: 10 Oct 2007

WHO. 2009. Numerical list of environmental heath criteria EHCs. In: International Program on Chemical safety, World Health Organization. http://www.who.int/ipcs/ publications/ehc/ehc_numerical/en/index.htm. Accessed: 20 Jan 2009 